\title{
A SEARCH FOR VERTICILLIUM RESISTANCE IN STRAWBERRY VARIETIES ${ }^{1}$
}

\author{
M. C. J. van Adrichem² and J. E. Bosher \\ Canada Department of Agriculture, Saanicbton, British Columbia
}

[Received for publication December 4, 1961]

\begin{abstract}
Out of 26 strawberry varieties, only Sierra was resistant to Verticillium albo-atrum R \& B. Climax, Marshall, Magoon, and Auchincruive No. 6, however were tolerant. Climax, Marshall, Northwest, Oberschlesien, Perle de Prague, Red Crop, Sierra, and Temple, when selfed, yielded a high percentage of resistant seedlings, suggesting that these varieties have promise as parent material in the breeding of commercial varieties for Verticillium wilt resistance. Fragaria chiloensis from two geographical areas yielded resistant seedlings in contrast with $F$, vesca americand which produced neither resistant nor tolerant seedlings. $F$, virginiana yielded tolerant but no resistant seedlings.
\end{abstract}

\section{INTRODUCTION}

The losses through Verticillium wilt in strawberries in British Columbia have previously been noted (1), together with the resistance, tolerance or susceptibility or seedlings derived from native species $(2,3)$. The present study is a search for promising parent material that could be used in the breeding of new commercial varieties resistant to the disease. It covers the resistance, tolerance, or the susceptibility to the disease of 26 commercial varieties and the response of seedlings derived therefrom through selfing. The study of native species has been extended.

\section{MATERIALS AND METHODS}

In the variety tests, ten young runner plants of each variety were used. The progeny tests were carried out with 2-month-old seedlings; the number used is indicated in Table 1. All plants and seedlings were inoculated with the same strain of Verticillium albo-atrum $\mathrm{R} \& \mathrm{~B}$, which is particularly virulent on strawberry and identical with the one used in previous work $(2,3)$. The method of inoculation consisted of placing the roots of the plants in a spore suspension for 24 hours. After the initial inoculation the plants were inoculated in the same manner twice, at 8-week intervals. After each 8-week period the plants were rated as follows: Plants showing symptoms of infection after the first or second inoculation were classed as susceptible and discarded; those showing symptoms after the third 8-week period as tolerant; resistant plants, showing no symptoms of infection after the third inoculation. The term "tolerant" as used in this work can be defined as moderately resistant to the pathogen. Further details about inoculation and the rating of the plants have been described previously (2).

\section{Variety Tests}

\section{RESULTS AND DISCUSSION}

The following data suggest that resistance to Verticillium wilt is rare in commercial varieties. Only one variety, Sierra, out of twenty-six commercial varieties of strawberries, proved to be resistant. Since the resistance

\footnotetext{
${ }^{1}$ Contribution No. 181, Experimental Farm, Research Branch, Canada Department of Agriculture, Saanichton, B.C.

Present address: Canada Department of Agriculture, Prince George, B.C.
} 
of Sierra might have been against the particular strain of the fungus used as the standard inoculum, this variety was inoculated with six other isolates from strawberry and one from tomato, and the same degree of resistance was displayed. Four varieties, Climax, Magoon, Marshall, and Auchincruive No. 6, were tolerant; that is, the fungus was only mildly pathogenic towards them.

Sierra is a California variety and not considered to be acceptable as a commercial strawberry variety in British Columbia. Marshall is a popular variety in the Pacific Northwest, and Magoon was the chief commercial variety in British Columbia until it was replaced by British Sovereign some 30 years ago.

The following varieties were all susceptible: Aberdeen, Agassiz, British Sovereign, Cambridge Early, Cambridge Sentry, Cambridge Rival, Deutsch Evern, Huxley, Macherauchs Frühernte, Madame Lefebvre, Madame Moutot, Northwest, Oberschlesien, Premier, Perle de Prague, Red Crop, Regina, Siletz, Sparkle, Stelemaster, Temple, and Ydun.

This study suggests that, at the present time, none of the varieties recommended for planting in British Columbia is resistant to Verticillium wilt.

Table 1.-ResistaAce to verticillium Wilt in Progeny of SELFED VARIETIES AND SPECIES

\begin{tabular}{|c|c|c|c|c|}
\hline \multirow{2}{*}{ Variety or Species } & \multirow{2}{*}{$\begin{array}{c}\text { No. of } \\
\text { seedlings } \\
\text { inoculated }\end{array}$} & \multicolumn{3}{|c|}{ Per cent } \\
\hline & & Susceptible & Tolerant & Resistant \\
\hline $\begin{array}{l}\text { Aberdeen (chance seedling) } \\
\text { Agassiz (Pathfinder x British } \\
\text { Sovereign) } \\
\text { British Sovereign (chance seedling) } \\
\text { Climax (Aberdeen x F Frith) } \\
\text { Huxley (Ettersburg seedling?) } \\
\text { Madame Lefebvre } \\
\text { Marshall (chance seedling) } \\
\text { Northwest (Brightmore x complete } \\
\quad \text { hybrid from Narcissa, } \\
\text { Ettersburg and Wilson) } \\
\text { Oberschlesien } \\
\text { (Sharpless x Ruhm von Köthen) } \\
\text { Perle de Prague } \\
\text { Red Crop (Aberdeen x Fairfax) } \\
\text { Siletz (US. -0.2021 x US.-0.1816) } \\
\text { Sierra (Nich Ohmer x Cal. 177.21) } \\
\text { Temple (Aberdeen x Fairfax) } \\
\text { Ydun (Deutsch Evern x Späte } \\
\text { von Leopoldshall x Culver) } \\
\text { Auchincruive No. 6 F from Frith } \\
\text { Fragaria chiloensis } 3 \text { Sooke, B.C. } \\
\text { F. chiloensis } 14 \text { Point Sur, California } \\
\text { F. vesca americana, Danford Lake, } \\
\text { Quebec } \\
\text { F. virginiana } 4 \text { Cushing, Quebec }\end{array}$ & $\begin{array}{r}100 \\
\\
100 \\
25 \\
100 \\
100 \\
100 \\
50 \\
\\
90 \\
100 \\
40 \\
50 \\
\\
100 \\
100\end{array}$ & $\begin{array}{l}88 \\
84 \\
84 \\
82 \\
87 \\
84 \\
78 \\
\\
94.4 \\
97 \\
47.5 \\
76 \\
100 \\
88\end{array}$ & $\begin{array}{r}3 \\
5 \\
4 \\
7 \\
8 \\
5 \\
14 \\
- \\
35 \\
14 \\
12\end{array}$ & $\begin{array}{c}9 \\
11 \\
12 \\
11 \\
5 \\
11 \\
8 \\
\\
5.6 \\
3 \\
17.5 \\
10 \\
- \\
-\end{array}$ \\
\hline
\end{tabular}




\section{Progeny Tests}

The data in Table 1 suggest that 8 commercial varieties, namely Climax, Marshall, Northwest, Oberschlesien, Perle de Prague, Red Crop, Sierra, and Temple, have promise as parent material in the breeding of strawberries for Verticillium resistance. The promise is based upon the high percentage of resistant seedlings among the progeny of these varicties when selfed. Wilhelm (4) has already reported the occurrence of resistant plants among the progeny of susceptible varieties. The data also show that the resistance of Sierra is not homozygous, since only 11 per cent of its progeny when selfed proved to be resistant.

The tests of the progeny of selfed Fragaria cbiloensis from two geographical areas indicate that this species contains genes of resistance, for 17 and 10 per cent, respectively, of the seedlings were resistant. On the other hand, no tolerant or resistant seedlings were found among the progeny of selfed $F$. vesca americana. Likewise, selfed $F$. virginiana yielded no resistant seedlings but this species has some promise as parent material for it produced 12 per cent tolerant seedlings.

\section{REFERENCES}

1. McKeen, W. E., and J. E. Bosher. 1955. Verticillium wilt of strawberries in British Columbia. Plant Disease Reptr. 39:371-372.

2. Newton, W., and M. C. J. van Adrichem. 1958. Resistance of Verticillium wilt in $\mathrm{F}_{1}$ generations of self-fertilized species of Fragaria. Can. J. Botany 36:279-299.

3. Van Adrichem, M. C. J., and W. R. Orchard. 1958. Verticillium wilt resistance in the progenies of Fragaria cbiloensis from Chile. Plant Disease Reptr. 42:13911393.

4. Wilhelm, S. 1955. Verticillium wilt of the strawberry with special reference to resistance. Pliytopathology 45:387-391. 